\title{
Influence of Improvisedteaching Instructional Materials on Chemistry Students' Performance in Senior Secondary Schools in Vandeikya Local Government Area of Benue State, Nigeria
}

\author{
Eriba Emmanuel Otor PhD (Corresponding author) \\ Department of Curriculum and Teaching, Benue State University \\ Makurdi, Nigeria \\ Tel: 234-8067-890-766_E-mail: Otoreriaemmanuel@gmail.com \\ Josiah Ogbeba PhD \\ Department of Curriculum and Teaching, Benue State University, \\ Makurdi, Nigeria
}

Tel: 234-806-972-8232

Clementina Ngunan Ityo

Department of Curriculum and Teaching, Benue State University,

Makurdi, Nigeria

Received: December 10, 2014 Accepted: January 8, 2015 Published: March 3, 2015

doi:10.5296/ire.v3i1.7181 URL: http://dx.doi.org/10.5296/ire.v3i1.7181

\begin{abstract}
This study assessed the use of improvised instructional materials on the performance of chemistry students. It also examined the differential performance among male and female chemistry students when this method is used in teaching chemistry. Two research questions and two hypotheses guided this study. A descriptive survey design was used for the study. Data were collected from 150 senior secondary school chemistry students using simple
\end{abstract}


random sampling procedure from eight secondary schools in Vandeikya Local Government Area of Benue State, Nigeria. Improvised Chemistry Teaching Aids Questionnaire (ICTAQ) developed by the researchers and validated by experts was used for data collection. The research questions were answered using mean and standard deviation while the hypotheses were tested at 0.05 level of significance using Analysis of Variance (ANOVA). Students taught using improvised instructional materials outperformed their counterparts taught with conventional lecture method. There was also a better performance among the male chemistry students when compared to their female counterparts. Based on the findings of the study, it was recommended among others that teaching of chemistry using improvised instructional materials should be encouraged since it facilitates the learning of this subject.

Keywords: improvised instructional materials, chemistry teaching, gender related, performance in chemistry

\section{Introduction}

Chemistry is an exact and a core science subject in Nigerian secondary schools. Its teaching often requires creativity and improvisation. To make chemistry concepts comprehensible to students, chemistry teachers must employ creative teaching methods and be prepared to respond to queries and explain concepts in an atypical manner (Nbina, 2012). The author further pointed out that the widespread poor performance and the negative attitude towards chemistry from secondary school students have largely been ascribed to lack of proper teaching methods. Teachers who adapt appropriate improvisation materials in teaching chemistry will likely be more successful in imparting chemistry knowledge to the novice chemists in their classes.

Samba and Eriba (2011) see improvisation as the act of using alternative materials and resources to facilitate instructions whenever there is lack or shortage of specific first hand teaching aids. The authors see improvisation as the choice of the best instructional material which enables the teacher to achieve some carefully specified educational objectives. Stiggins (2008) added that there are various methods used to increase class participation and performance among students. The researchers hope that improvisation of instructional teaching materials could be one of them. Recent models of teaching and learning view learning as a social activity in which children construct knowledge with the teacher and other children (Kerry, 2002).

Chemistry is a branch of physical science, and it is the study of the composition, properties and behaviour of matter. Since it's a physical science, its teaching has to be physical and real (Baja, 1988). The teaching of chemistry is made interesting with the use of teaching aids which include flash cards, pointer, computers, improvised materials and overhead projectors among others. The knowledge of this subject is control to vocations in health services, pharmaceuticals, petroleum and petrochemical industries, food processing, teaching services and extractive industries, which is relevant for economic development. The teaching of this subject should aim at developing in the students those manipulative and experimental skills necessary to make them competent and confident in the investigations of the material resources around them. However, as important as this subject is to all science related 
vocations, the performance of students in it at the senior secondary school certificate levels has not met the desired needs of the nation hence the need for this investigation.

\subsection{Theoretical Framework for the Study}

This research work is anchored on Bruner (1966) learning discovery and Ausubel (1963) theory of meaningful learning. Bruner proposes that learning is a highly complex activity which involves three major processes, namely, acquisition of information, manipulation or transformation of this information into a form suitable for dealing with the task at hand and testing and checking the adequacy of this information. Igwe, Arop and Ibe (2013) suggested that students should be given opportunity to discover and invent things. This allows teachers to extend their lesson to a wider range of students and increase participation through individualized process. Through this method, students are able to make personal connections to their own interests and are encouraged to express their own opinions (Berk, 2009). Hence the teacher should allow the students to acquire skills that will make them learn on their own. The poor achievement of students in chemistry has continued to be a major cause of concern to all, particularly those in the mainstream of science education in Nigeria (Akpoghol, 2001).

While Ausubel proposes that learning is only meaningful to the extent to which the learner can integrate existing learning or knowledge with new ones. This theory emphasizes how prior knowledge affects the learning process of new learning task. To make learning more meaningful, lively, understandable and real, appropriate instructional methods must be applied (Ilarbor \& Chukurdi, 2008). Mboto, Ndem and Stephen (2011) added that the use of improvised instructional materials enhanced teaching of science and improved performance.

\section{Statement of the Problem}

It is being observed that memorization of facts have replaced experimentation in chemistry among students in secondary schools. This is sad because this subject is expected to a life science. Due to this attitude of chemistry students towards the learning of this subject, its advancement and breakthrough remains a hope of many decades to come. This study therefore attempts to find out if the use of improvised teaching instructional materials could improve the performances of students in this subject at the senior secondary school.

\section{Purpose of the Study}

The purpose of this study is to determine the impact of improvised instructional materials on the academic performance of chemistry students at the senior secondary school level. The study specifically addresses the level of application of improvised teaching materials of chemistry teachers at this level and students' performance.

\section{Research Questions}

The following research questions were addressed in the study:

i. What is the impact of the use of improvised teaching materials on the performance of senior secondary school chemistry students? 
ii. To what extent do the performance of male and female students differ when taught using improvised instructional materials?

\section{Null Hypotheses}

To determine the effectiveness of this study, the following hypotheses were formulated and tested at 0.05 level of significance.

Ho: : There is no significant difference in performance among chemistry students when taught using improvised teaching materials and those taught using conventional lecture method.

$\mathbf{H o}_{2}$ : There is no significant difference in performance among male and female chemistry students when taught using improvised instructional materials.

\section{Methodology}

This section deals with the research design, population, area of study, sample and sampling, instrumentation and the statistical tools used for data analyses. A non parametric descriptive statistics was used for this study. The target population of this study was all SS 2 chemistry students in Vandeikya Local Government Area of Benue State of Nigeria. A sample of 150 male and female chemistry students representing $15.26 \%$ of the total population of 983 was used for the study.

A research instrument which was validated by experts, chemistry educators, measurement and evaluation was used for this study namely Improvised Chemistry Teaching Aids Questionnaire (ICTAQ). The instrument was administered directly by the researchers to the respondents. The researchers were also responsible for the collection of data. The ICTAQ was made up of twenty three statements from different improvised approaches in teaching chemistry. The researchers personally administered this instrument directly to the respondents and also the data were collected by them. The research questions were answered using mean and standard deviations while the hypotheses were tested using one-way Analysis of Variance (ANOVA).

\section{Results and Discussion of Findings}

The results of this investigation are presented according to research questions and hypotheses.

\subsection{Research Question One:}

The research question sought information on the extent to which improvised teaching instructional materials improve the performance of senior secondary school students in chemistry. 
Table 1. Mean and Standard Deviation scores for the impact of improvised teaching aids in Chemistry

\begin{tabular}{llllll}
\hline S/N & Impact of improvised teaching aid & Freq. & Mean & $\begin{array}{c}\text { Std. } \\
\text { Deviation }\end{array}$ & Remarks \\
\hline 1 & $\begin{array}{l}\text { Improvised teaching instructional materials help } \\
\text { facilitate my understanding of Chemistry }\end{array}$ & 149 & 1.000 & .0816 & Has impact \\
2 & $\begin{array}{l}\text { Improvised teaching instructional materials help } \\
\text { concretize abstract concepts in Chemistry }\end{array}$ & 146 & 1.000 & .1616 & Has impact \\
3 & $\begin{array}{l}\text { Improvised teaching instructional materials } \\
\text { gives me a clearer meaning of concepts being } \\
\text { taught. }\end{array}$ \\
$\begin{array}{l}\text { Improvised teaching instructional materials help } \\
\text { me retain the concepts being taught }\end{array}$ & 113 & 1.000 & .2757 & Has impact \\
\hline
\end{tabular}

From Table 1, 149 respondents indicates that, improvised teaching instructional materials help facilitate my understanding of chemistry, 146 stated that improvised teaching instructional materials help concretize abstract concepts in chemistry, 141 respondents agree that improvised teaching instructional materials gives a clear meaning of concepts being taught while 113 agreed that improvised teaching instructional materials help retain the concept being taught.

\subsection{Research Question Two}

The research question sought information on the extent do the performance of male and female students differ when taught using improvised teaching instructional materials.

Table 2. Mean and Standard Deviation scores for the difference on male and females differ when taught using improvised teaching instructional materials

\begin{tabular}{|c|c|c|c|c|c|}
\hline $\mathbf{S} / \mathbf{N}$ & Differences & Freq. & Mean & $\begin{array}{c}\text { Std. } \\
\text { Deviation }\end{array}$ & Remarks \\
\hline 1 & $\begin{array}{l}\text { Male students perform better in chemistry when } \\
\text { taught using improvised materials }\end{array}$ & 148 & 1.026 & .2301 & $\begin{array}{l}\text { Significant } \\
\text { difference }\end{array}$ \\
\hline 2 & $\begin{array}{l}\text { Female students perform better when taught } \\
\text { using improvised teaching instructional } \\
\text { materials }\end{array}$ & 145 & 1.053 & .3018 & $\begin{array}{l}\text { Significant } \\
\text { difference }\end{array}$ \\
\hline 3 & $\begin{array}{l}\text { Male students understand chemistry better when } \\
\text { taught using improvised instructional materials }\end{array}$ & 145 & 1.066 & .3602 & $\begin{array}{l}\text { Significant } \\
\text { difference }\end{array}$ \\
\hline 4 & $\begin{array}{l}\text { Female students understand chemistry better } \\
\text { when taught using improvised materials }\end{array}$ & 145 & 1.053 & .3018 & $\begin{array}{l}\text { Significant } \\
\text { difference }\end{array}$ \\
\hline
\end{tabular}

From Table 2, it was indicated that, 148 males perform better in chemistry when taught using improvised teaching materials, 145 respondents female students perform better when taught using improvised teaching instructional materials, 145 respondents indicated that male students understand chemistry better when taught using improvised instructional materials 
while 145 respondents agree that female students understand chemistry better when taught using improvised materials.

\subsection{Null Hypothesis $\left(\mathrm{Ho}_{1}\right)$}

It stated that "there will be no significant difference in the performance of students in chemistry on the basis of being taught using improvised materials and those that are taught using conventional method". In testing this hypothesis, a one-way Analysis of Variance (ANOVA) was used.

Table 3. ANOVA scores of the difference in the performance of students in chemistry on the basis of being taught using improvised materials and those that are taught using conventional method

\begin{tabular}{llllll}
\hline & Sum of squares & df & Ms & F & Sig. \\
\hline Between groups & 84.410 & 148 & 32.205 & 68.815 & .000 \\
Within groups & 65.812 & 2 & .468 & & \\
Total & 149.900 & 150 & & & \\
\hline
\end{tabular}

Results from Table 3, show that, there is a significant difference between those taught using improvised teaching instructional materials and those taught using conventional method. F (2, $148)=68.815, \mathrm{p} \leq .005$.

\subsection{Null Hypothesis $\left(\mathrm{Ho}_{2}\right)$}

It stated that "there is no significant difference in performance among male and female chemistry students using improvised teaching method". In testing this hypothesis, a one-way Analysis of Variance (ANOVA) was used.

Table 4. ANOVA scores of the difference in performance between male and female chemistry students taught using improvised teaching method

\begin{tabular}{llllll}
\hline & Sum of squares & df & Ms & F & Sig. \\
\hline Between groups & 85.306 & 2 & 5.102 & 7.22 & .000 \\
Within groups & 64.916 & 148 & .706 & & \\
Total & 149,923 & 150 & & & \\
\hline
\end{tabular}

Results from the Table four, above show that, there is a significant difference in performance between males and female students using improvised teaching methods, $F(2,148)=7.22$, $p$ $\leq .05$.

\subsection{Discussion of Results}

Results in Table 2 reveal that students that were taught using improvised instructional 
materials performed better in chemistry than those that were taught using conventional lecture method. This is further confirmed in Table 6 which indicates that method is a significant factor in the performance of chemistry students $F(2,148)=68.815, p \leq .005$. It implies that students who were taught using improvised instructional materials were better in attainment when compared with their counterparts that were taught using conventional lecture method.

The results in Table 3 indicate that method is also a significant factor in the performance of male and female chemistry students when taught using improvised instructional materials. Table 3 reveals that the male subject performed better than their female counterparts using this instructional method of teaching, $\mathrm{F}(2,148)=7.22, \mathrm{P} \leq .05$. The implication of this is that improvised instructional material is a factor in achievement between male and female chemistry students.

The reason for this positive achievement by chemistry students that were exposed to the use of improvisation is because they were in touch with the actual (physical) instructional materials. This finding agrees with the work of Oladejo, Olusunde, Ojebisi and Isola (2011) who reported that hate widespread poor performance and negative attitude of secondary school students towards chemistry has been largely ascribed to teaching problems like the inadequate standardized teaching instructional materials.

\section{Conclusion and Recommendations}

The students who were taught using the improvised instructional materials performed better in chemistry than their counterparts that were taught using conventional lecture method. There was no significant difference in performance between the male and female chemistry students when taught using improvised instructional materials.

Based on the findings of this work, the following recommendations were made:

a. Chemistry teachers should accept the use of improvised instructional materials as a method in teaching chemistry since it is found to be effective.

b. Teaching of chemistry using improvised instructional materials to female chemistry students should not only be encouraged but emphasis should be given to this sex to step up their performance in this subject.

\section{References}

Akpoghol, T. (2001). Poor Performance in Science Subject amongst Secondary School Students in Makurdi: Causes and Possible Solutions. Unpublished P.G.D.E. Project, Benue State University, Makurdi.

Ausubel, D. P. (1963). The Use of Advance Organizer in Learning and Retention of Meaningful Verbal Materials. Journal of Educational Psychology, 51, 267-272. http://dx.doi.org/10.1037/h0046669

Baja, S. T. (1988). Senior Secondary Chemistry. Lagos: Longman. 
Berk, L. E. (2009). Development through the Life Span. Bostson, M.A: Pearson Education.

Bruner, J. S. (1966). Towards a Theory of Instruction. Cambridge: Harvard University Press.

Igwe, I. O., Arop, B. A. \& Ibe, J. O. (2013). Problems of Improvising Instructional Materials for the Teaching and Learning of Chemistry. STAN Annual Conference.

Ilarbor, S. C. \& Chukurdi, J. (2008). Instructional Resource for Chemistry Curriculum Development in Nigeria Secondary Schools. STAN Conference Proceedings, STAN Annual Conference.

Kerry, T. (2002). Explaining and Questioning. Cheltenham, U.K.: Nelson Thomes.

Mboto, F. A., Ndem, N. U. \& Stephen, U. (2011). Effects of Improvised materials on Student's Achievement and Retention of the Concept of Radioactivity. African Research Review, An International Multi-Disciplinary Journal, Ethiopia, 5(1), 342-348.

Nbina, J. B. (2012). Analysis of Poor Performances of Senior Secondary Students in Chemistry in Nigeria. African Research Review, An International Multi-Disciplinary Journal, Ethiopia, 6(4), 319-330.

Oladejo, M. A., Olosunde, G. R., Ojebisi, A. O. \& Isola, O. M. (2011). Instructional Materials and Student Academic Achievement in Physics, Some Policy Implications. European Journal of Humanities and Social Science, 2(1), 187-190.

Samba, R. M. O, \& Eriba, J. O. (2011). Laboratory Techniques and the Art of Improvisation. Makurdi: His Masters Servant Media Apostolate Publications.

Stiggins, R. (2008). An Introduction to Student Involved Assessment for Learning (5th ed.). New Jersey: Pearson Education Inc. Research Based Practice to Engage every Learner. Thousand Oaks, California: Sage.

\section{Copyright Disclaimer}

Copyright reserved by the authors.

This article is an open-access article distributed under the terms and conditions of the Creative Commons Attribution license (http://creativecommons.org/licenses/by/3.0/). 